Article

\title{
Exploring the Use of Fruit Callus Culture as a Model System to Study Color Development and Cell Wall Remodeling during Strawberry Fruit Ripening
}

\author{
Pablo Ric-Varas ${ }^{1}\left(\mathbb{D}\right.$, Marta Barceló ${ }^{2}$, Juan A. Rivera ${ }^{1}$, Sergio Cerezo ${ }^{1}$, Antonio J. Matas ${ }^{1}{ }^{(D}$, \\ Julia Schückel ${ }^{3}$, J. Paul Knox ${ }^{4}$, Sara Posé ${ }^{1}$, Fernando Pliego-Alfaro ${ }^{1}$ and José A. Mercado ${ }^{1, *(D)}$ \\ 1 Instituto de Hortofruticultura Subtropical y Mediterránea “La Mayora” (IHSM-UMA-CSIC), \\ Departamento de Botánica y Fisiología Vegetal, Universidad de Málaga, 29071 Málaga, Spain; \\ pabloric@uma.es (P.R.-V.); juan89_uma@hotmail.es (J.A.R.); scerezo@uma.es (S.C.); \\ antoniojmatas@uma.es (A.J.M.); sarapose@uma.es (S.P.); ferpliego@uma.es (F.P.-A.) \\ 2 IFAPA Centro de Málaga, Cortijo de la Cruz s/n, 29140 Málaga, Spain; marta.barcelo@juntadeandalucia.es \\ 3 Department of Plant and Environmental Sciences, University of Copenhagen, 1871 Frederiksberg, Denmark; \\ js@glycospot.dk \\ 4 Centre for Plant Sciences, Faculty of Biological Sciences, University of Leeds, Leeds LS2 9JT, UK; \\ j.p.knox@leeds.ac.uk \\ * Correspondence: mercado@uma.es
}

Received: 8 June 2020; Accepted: 24 June 2020; Published: 27 June 2020

\begin{abstract}
Cell cultures derived from strawberry fruit at different developmental stages have been obtained to evaluate their potential use to study different aspects of strawberry ripening. Callus from leaf and cortical tissue of unripe-green, white, and mature-red strawberry fruits were induced in a medium supplemented with $11.3 \mu \mathrm{M}$ 2,4-dichlorophenoxyacetic acid (2,4-D) under darkness. The transfer of the established callus from darkness to light induced the production of anthocyanin. The replacement of 2,4-D by abscisic acid (ABA) noticeably increased anthocyanin accumulation in green-fruit callus. Cell walls were isolated from the different fruit cell lines and from fruit receptacles at equivalent developmental stages and sequentially fractionated to obtain fractions enriched in soluble pectins, ester bound pectins, xyloglucans $(X G)$, and matrix glycans tightly associated with cellulose microfibrils. These fractions were analyzed by cell wall carbohydrate microarrays. In fruit receptacle samples, pectins were abundant in all fractions, including those enriched in matrix glycans. The amount of pectin increased from green to white stage, and later these carbohydrates were solubilized in red fruit. Apparently, XG content was similar in white and red fruit, but the proportion of galactosylated XG increased in red fruit. Cell wall fractions from callus cultures were enriched in extensin and displayed a minor amount of pectins. Stronger signals of extensin Abs were detected in sodium carbonate fraction, suggesting that these proteins could be linked to pectins. Overall, the results obtained suggest that fruit cell lines could be used to analyze hormonal regulation of color development in strawberry but that the cell wall remodeling process associated with fruit softening might be masked by the high presence of extensin in callus cultures.
\end{abstract}

Keywords: carbohydrate microarray; callus culture; cell culture; cell wall; extensin; fruit ripening; fruit softening; pectin

\section{Introduction}

Ripening of fleshy fruits is a complex developmental process involving changes in color, flavor, and texture that make the tissue edible to seed-dispersing animals [1]. From an agricultural point of view, textural changes are of major importance since the loss of firm texture is the main determinant of the 
postharvest shelf life in most commodities [2,3]. Furthermore, fruit texture is one of the main attributes for the acceptance in the market from the consumer's point of view [2]. Soft fruits such as strawberry acquire an undesirable melting texture very soon after ripening, increasing their susceptibility to pathogen attack and reducing their shelf life to a few days $[4,5]$.

It is generally accepted that the modification of the mechanical properties of the primary cell walls due to cell wall disassembly, the reduction of intercellular adhesion as a result of middle lamella dissolution, and the reduction in cell turgor are the major causes of fruit softening [6-9]. Among these three factors, most studies have focused on the cell wall disassembly process taking place during fruit ripening; however, despite the large amount of information available, a general model of cell wall remodeling leading to fruit softening remains elusive [9]. Functional analyses of genes encoding pectinases such as polygalacturonase and pectate lyase point to the pectin fraction as a key factor involved in strawberry softening $[10,11]$.

An additional area of active research in strawberry is the genetic regulation of fruit color. Anthocyanin is the principal pigment leading to the red color of ripe strawberry fruit [12,13]. Some key genes involved in the biosynthesis and the regulation of flavonoid/phenylpropanoid compounds have been characterized using transgenic approaches [12,14-16]. All these studies have been performed with whole strawberry fruit, a complex organ containing different tissues that differ in their metabolism and that undergo ripening at different rates.

In many cases, cell cultures can be used as simple model systems to study developmental processes, such as stem cell regulation, mineral deficiency, or disease and stress responses [17-20]. In vitro cultures provide a source of uniform plant material that can be easy to handle, avoiding complex interactions among different plant organs and/or tissues. In the case of fruit, calyx and fruit cultures as well as callus derived from fruit tissues have been employed to study different aspects of ripening, such as hormonal regulation [21], flavor and color development [22], or defense responses [23]. In strawberry, callus from immature fruit has been used to analyze phenol metabolism during the in vitro culture period and its relationship with cell growth [24,25]. Strawberry leaf callus has also been employed to characterize anthocyanin synthesis [26,27]. As regards cell wall metabolism, the effect of plant growth regulators in cell wall composition of callus cultures obtained from immature apple fruits has been determined [28]. As far as is known, the remodeling of cell walls associated with fruit softening has not yet been addressed using callus cultures. The aims of this study were firstly to produce cell lines from strawberry fruits at different developmental stages and secondly to characterize these lines to determine if they could be a useful model system to gain insight into the fruit ripening process, particularly into the regulation of anthocyanin synthesis and the cell wall disassembly associated with fruit softening.

\section{Results}

\subsection{Effect of Hormonal Balance and Explant Type on Strawberry Callus Development}

To optimize the generation of callus from strawberry tissue, leaf explants from micropropagated plants were cultured in $\mathrm{N}_{30} \mathrm{~K}$ medium supplemented with a combination of benzyladenine (BA) and 2,4-Dichlorophenoxyacetic acid (2,4-D) at different concentrations. The presence of 2,4-D in the medium was needed to induce the formation of friable callus; by contrast, BA diminished callus production. After 8 weeks of culture, the highest amount of callus was formed in leaf explants cultured in media only supplemented with 2,4-D (Figure 1). Calli induced in the different media were isolated and recultured into the same fresh medium. In all media only supplemented with 2,4-D as growth regulator, callus showed a good growth rate reaching mean weight values of 4.6, 4.7, and $5.3 \mathrm{~g}$ in 11.3 , 22.6, and 45.2 $\mu \mathrm{M}$ 2,4-D medium, respectively, at the end of the experiment after 16 weeks of culture. However, calli obtained in the media supplemented with BA did not increase their fresh weight after subsequent recultures to fresh medium. 
Sections of fruit receptacle at three developmental stages, immature-green, white, and ripe-red, were cultured in $\mathrm{N}_{30} \mathrm{~K}$ medium supplemented with $11.3 \mu \mathrm{M} 2,4-\mathrm{D}$ to induce callus formation. Although the rate of explant contamination was high, especially in red fruit $(>60 \%)$, several callus lines from fruit at each developmental stage could be recovered. One cell line was selected for each explant type and further multiplied (Figure 2). Afterwards, the growth curve of selected cell lines growing in $\mathrm{N}_{30} \mathrm{~K}-11.3 \mu \mathrm{M}$ 2,4-D medium was recorded (Figure 3). The highest growth rate was observed in callus from green-fruit followed by white- and red-fruit. Leaf callus displayed an intermediate behavior between white-fruit and red-fruit calli. The aspect of these cell lines was also different after 3 weeks of culture. White and red-fruit calli were white-beige with a creamy and watery texture. Green-fruit callus showed a similar color but a more compact and hard texture. Finally, leaf callus was yellowish and soft.

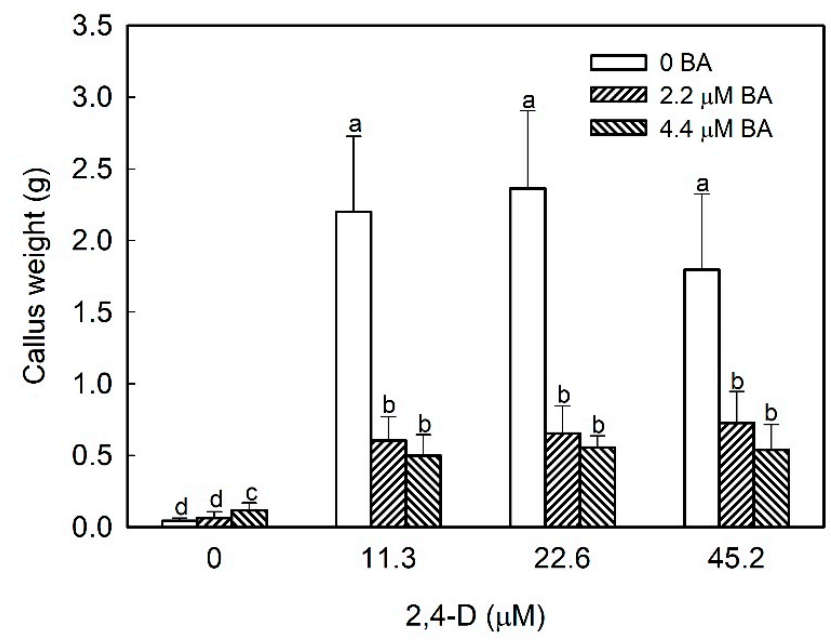

Figure 1. Effect of hormonal balance in callus development from strawberry leaf explants cultured in $\mathrm{N}_{30} \mathrm{~K}$ medium. Data were taken after 8 weeks of culture in the dark. Means with different letters indicate significant differences by Kruskal-Wallis test at $p=0.05$.

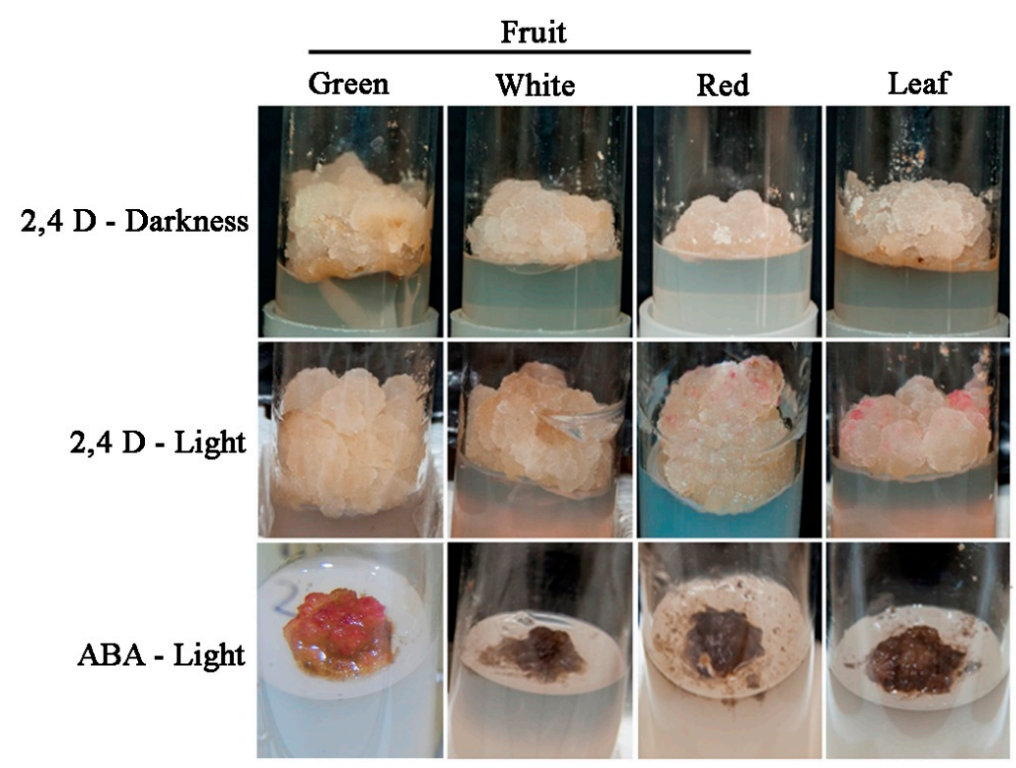

Figure 2. Aspect of calli obtained from leaf and fruit at different developmental stages growing in $\mathrm{N}_{30} \mathrm{~K}$ medium supplemented with $11.3 \mu \mathrm{M}$ 2,4-Dichlorophenoxyacetic acid (2,4-D) in darkness (2,4 D-darkness), the same medium under a $16 \mathrm{~h}$ photoperiod at $40 \mu \mathrm{mol} \cdot \mathrm{m}^{-2} \cdot \mathrm{s}^{-1}(2,4-\mathrm{D}$ light $)$ or $\mathrm{N}_{30} \mathrm{~K}$ medium with $1 \mu \mathrm{M}$ abscisic acid (ABA) under light conditions (ABA-light). Pictures were taken after 4 weeks of culture in the presence of 2,4-D and 2 weeks in the case of ABA. 


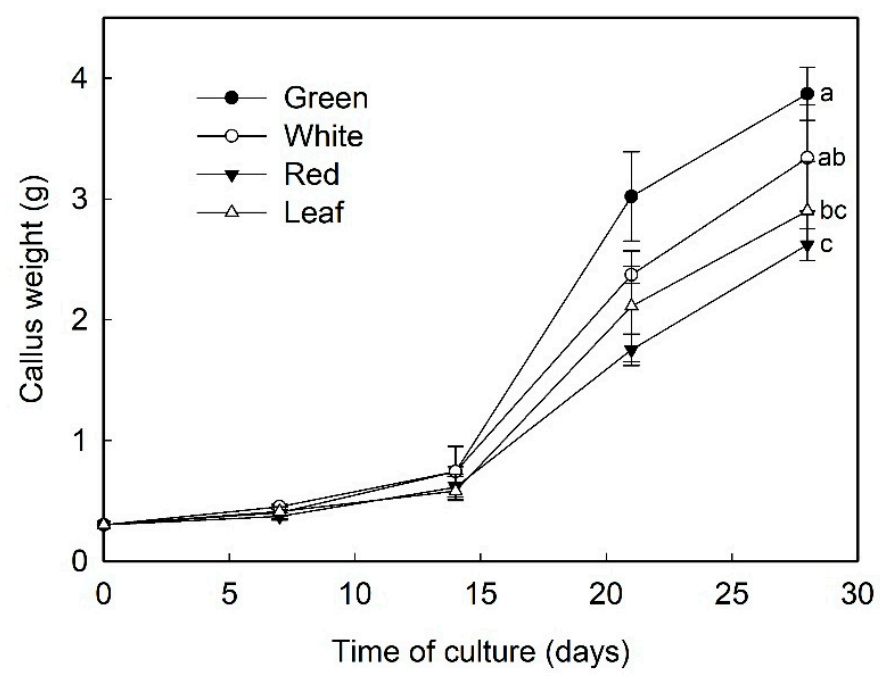

Figure 3. Growth curve of the different callus lines obtained from leaf and fruit receptacle at green, white, and red stages. Data represent mean \pm SD. At 28 days of culture, means with different letters indicate significant differences by Tukey test at $p=0.05$.

To further characterize the best conditions for strawberry callus proliferation, the effect of light incubation was analyzed. Thus, calli were cultured in $\mathrm{N}_{30} \mathrm{~K}-11.3 \mu \mathrm{M}$ 2,4-D and maintained in darkness or under a $16 \mathrm{~h}$ photoperiod of $40 \mu \mathrm{mol} \cdot \mathrm{m}^{-2} \cdot \mathrm{s}^{-1}$. Calli cultured under illumination exhibited a higher fresh weight than those incubated under darkness, with significant differences in the case of calli from green and white fruits (Figure 4). Interestingly, some sectors of calli incubated in light developed red pigmentation after three weeks of culture, especially in the case of leaf and red-fruit cell lines (Figure 2). Average value of anthocyanin content, measured as pelargonidin-3-glucoside, was $0.24 \pm 0.03 \mathrm{mg} / 100 \mathrm{~g}$ fresh weight in calli cultured in darkness; when calli were grown in light, the amount of anthocyanin increased, and the mean values ranged between $0.34 \pm 0.07$ and $0.45 \pm 0.09 \mathrm{mg} / 100 \mathrm{~g}$ in green-fruit and leaf callus, respectively.

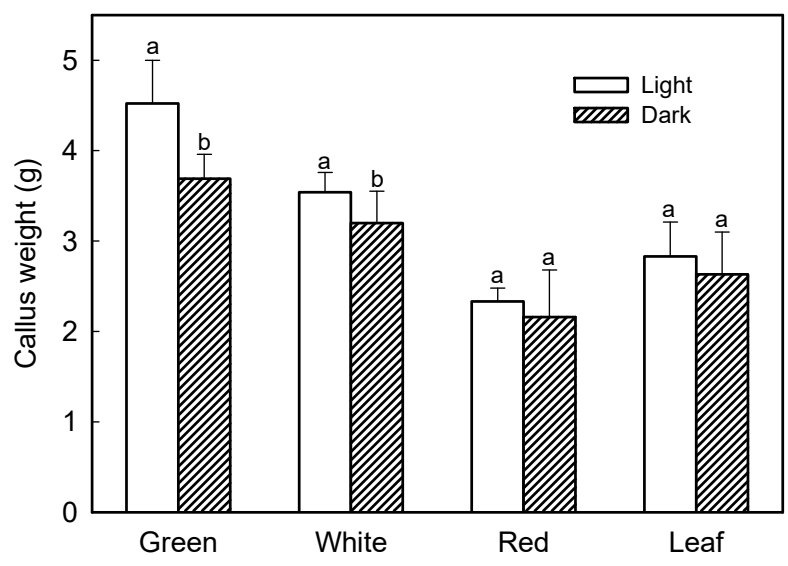

Figure 4. Effect of light incubation in the growth of calli obtained from strawberry leaf and fruits at different developmental stages. Within each callus line, columns with different letters indicate significant differences by Student's $t$-test at $p=0.05$.

\subsection{Effect of $A B A$ in the Production of Anthocyanin}

To determine if abscisic acid (ABA) enhanced the production of anthocyanin in strawberry calli cultured in the presence of light, cell lines were incubated in $\mathrm{N}_{30} \mathrm{~K}$ medium supplemented with different concentrations of ABA in the absence of auxin. A control treatment of callus cultured without growth regulators was also included. As previously observed, the transfer of calli cultured in the standard 
growth medium $(11.3 \mu \mathrm{M}$ 2,4-D) from dark to light conditions induced the production of anthocyanin, especially in leaf and red-fruit cell lines (Figure 5). The substitution of auxin by ABA at the lowest concentration $(1 \mu \mathrm{M})$ notably increased anthocyanin production in calli from green fruits and to a lesser extent in red-fruit line (Figures 2 and 5); however, leaf and white-fruit calli did not respond to this treatment. Higher ABA concentrations or the absence of growth regulators in the culture medium diminished cell viability, and most cells showed necrosis after 4 weeks of culture.

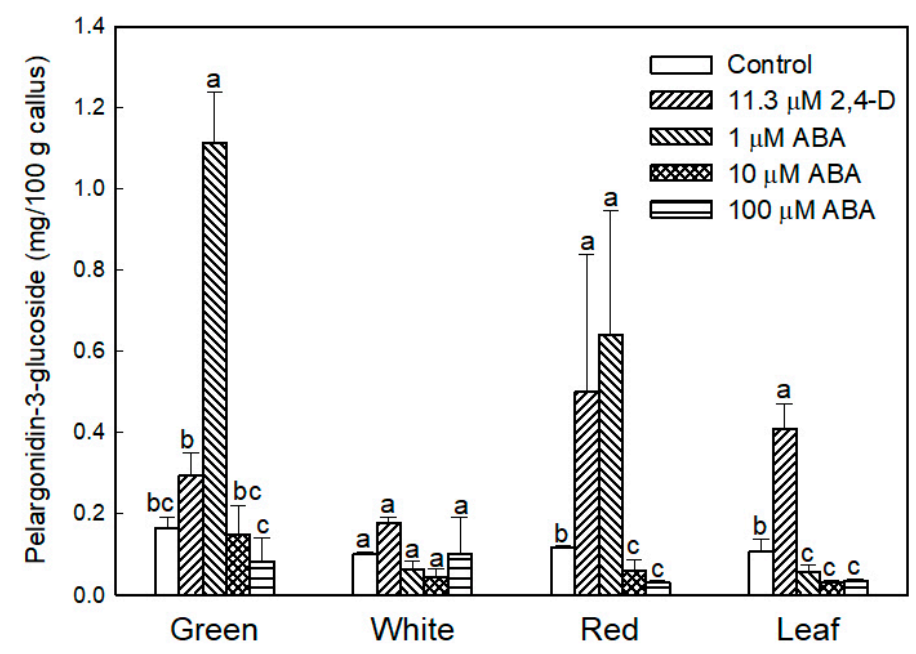

Figure 5. Anthocyanin production in calli obtained from strawberry leaf and fruits at different developmental stages after culturing for 2 weeks in $\mathrm{N}_{30} \mathrm{~K}$ medium with 2,4-D or ABA in the presence of light. Control: callus incubated in the absence of growth regulators. Within each callus line, columns with different letters indicate significant differences by Kruskal-Wallis test at $p=0.05$.

\subsection{Analysis of Cell Wall Components by Comprehensive Microarray Polymer Profiling (CoMPP)}

Cell walls from leaf and fruit cell cultures were extracted and treated with different solvents to yield fractions enriched in soluble and ester-bound pectins (water and sodium carbonate, respectively), xyloglucans (4M KOH), and matrix polysaccharides tightly linked into cellulose microfibrils (cadoxen). Cell walls from fruits at green, white, and red stages were subjected to the same fractionation process for comparison. Table 1 displays the antibodies used in the CoMPP analysis. A heatmap of the obtained carbohydrate microarray results is shown in Figure 6. LM27 mAb against grass xylan was included as negative control, and, as expected, no signal was detected in any sample. In the case of fruit cell walls, methylesterified homogalacturonan (HG), recognized by JIM7, was abundant in water fractions of green and white fruits, whereas red fruit showed higher signal of JIM5, which binds to low methylester and unesterified HG. Both HG and rhamnogalacturonan I (RGI) were detected in the sodium carbonate fraction as well as in $\mathrm{KOH}$ and cadoxen fractions, indicating that a large fraction of pectins remained linked to xyloglucan $(X G)$ and/or entrapped in cellulose microfibrils. In general, the amount of extractable pectins increased from green to white fruits and then declined in red fruit. $\mathrm{KOH}$ and cadoxen fractions contained significant amounts of XG, recognized by LM15 and LM25 mAbs. As observed for pectin epitopes, the amount of extracted XG increased from green to white fruits; however, in red fruits, the LM15 signal for the XXXG motif of XG diminished, while the LM25 signal additionally recognizing $X G$ galactosyl residues increased. Glucuronoxylan recognized by LM28 was also abundant in $\mathrm{KOH}$ and cadoxen fractions from green and red fruits. A low signal of arabinogalactan protein glycan (JIM13) was detected in the $\mathrm{KOH}$ fraction, increasing in amount as the fruit ripen. 
Table 1. List of monoclonal antibodies used in the carbohydrate microarray and the epitopes recognized by each $\mathrm{mAb}$.

\begin{tabular}{cc}
\hline Antibody & Cell Wall Epitope \\
\hline LM18, LM19, JIM5 & Partially Me- homogalacturonan $(\mathrm{HG}) /$ no ester \\
JIM7 & Partially Me-HG \\
LM5 & $(1 \rightarrow 4)-\beta$-D-galactan \\
LM6-M & $(1 \rightarrow 5)-\alpha$-L-arabinan \\
INRA-RU1, INRA-RU2 & {$[\rightarrow 2)$ - $\alpha$-L-rhamnose- $(1 \rightarrow 4)-\alpha$-D-galacturonic acid- $(1 \rightarrow]_{7}$} \\
LM13 & Linearized $(1 \rightarrow 5)$ - $\alpha$-L-arabinan \\
LM26 & Branched galactan \\
LM15 & Xyloglucan $(X X X G$ motif $)$ \\
LM25 & XXXG/galactosylated xyloglucan \\
LM11 & $(1 \rightarrow 4)-\beta$-D-xylan/arabinoxylan \\
LM23 & Non-acetylated xylosyl \\
LM28 & Glucuronoxylan \\
LM1, JIM11, JIM20 & Extensin \\
JIM13 & Heteromannan \\
LM21 & Grass heteroxylan \\
LM27 & Arabinogalactan-protein (AGP glycan \\
\hline
\end{tabular}

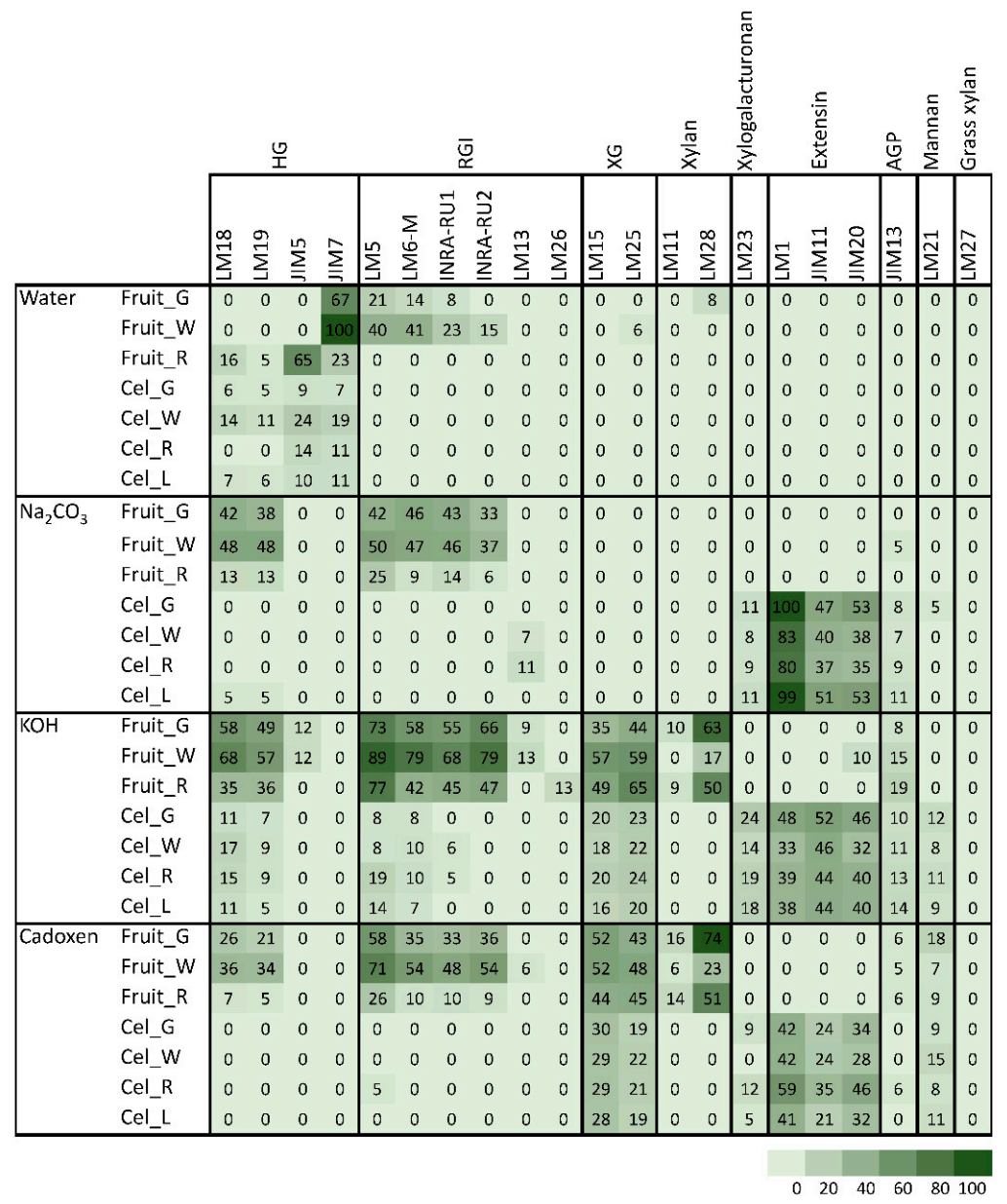

Figure 6. Heat map showing the relative abundance of cell wall epitopes recognized by different mAbs in cell wall fractions extracted from strawberry fruits and cell cultures obtained from leaf and fruit receptacle at different developmental stages. A value of 100 was assigned to the highest mean spot signal, and all other signals were adjusted accordingly. Fruit_G: unripe-green fruit; Fruit_W: white fruit; Fruit_R: mature-red fruit; Cel_G: callus from green fruit; Cel_W: callus from white fruit; Cel_R: callus from mature-red fruit; Cel_L: callus from leaf. 
Polysaccharide profiles of cell walls from callus cultures were quite different from the one described for fruits. In all cell wall fractions, HG and RGI pectin mAbs displayed a very low signal. The amounts of $\mathrm{XG}$ and xylan in $\mathrm{KOH}$ and cadoxen fractions were also lower than in fruit fractions. By contrast, the three mAbs against extensin, LM1, JIM11, and JIM20 showed strong signals in cell culture fractions and were highest in the sodium carbonate fraction. Extensin epitopes were not detected in fruit samples or in the water fraction from callus cultures. LM23 also showed a different profile in fruit and cell cultures. This $\mathrm{mAb}$ binds to xylogalacturonan, and it was detected in all fractions from callus lines except water fraction but was absent in fruit cell walls.

A principal component analysis (PCA) was performed to provide an overview of sample group separation (Figures 7 and 8). In the four cell wall fractions, the first principal component accounted for most of the variability in the data set $(>67 \%)$. Samples from fruit and cell cultures were separated along this first principal component, with fruit samples in the positive values and cell cultures in the negative values. The only exception was the water fraction from ripe fruit that appeared close to cell culture samples (Figure 7). mAbs against neutral carbohydrates and RGI backbone (LM5, LM6-M, INRA-RU1) as well as JIM7 against methylesterified HG correlated positively with the first dimension in the case of water fractions. In the sodium carbonate fraction, mAbs related to RGI and unesterified HG (LM19, LM18) contributed positively to the first principal component, while extensin mAbs (JIM11, JIM29, and LM1) contributed negatively. $\mathrm{KOH}$ and cadoxen fractions followed a similar trend, although XG related mAbs (LM23 and LM25) also correlated negatively with the first component. The results obtained indicate that the first PCA dimension, accounting for most of the variability in the samples, was related to the amount of pectins in the water fraction and the substitution of pectins by extensin epitopes in the rest of fractions.
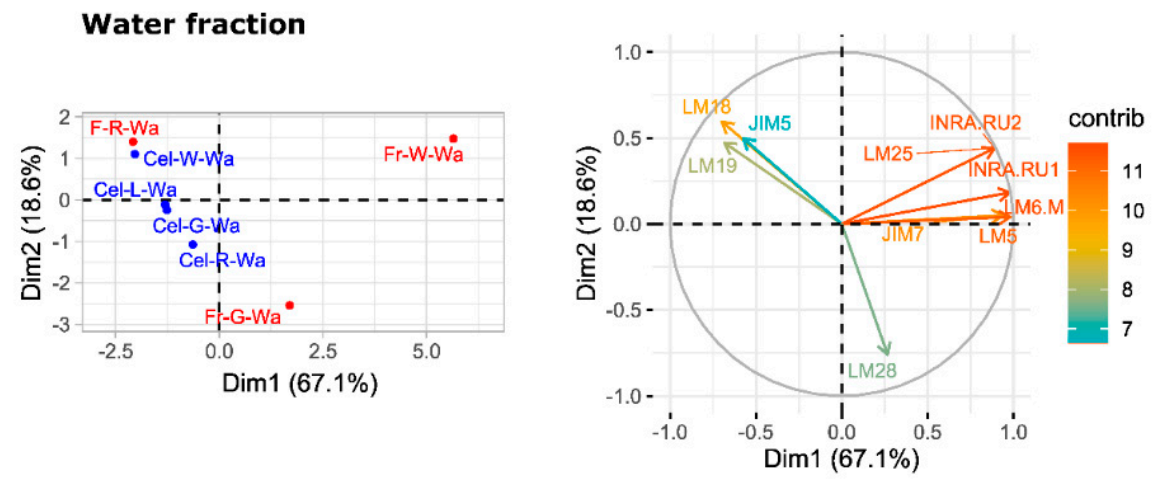

Sodium carbonate fraction
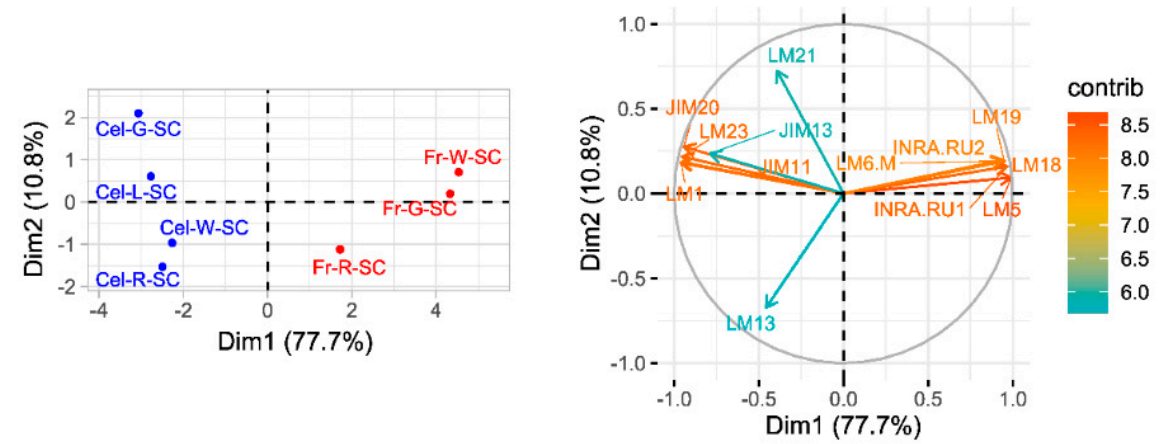

Figure 7. PCA analysis of carbohydrate microarray data from pectin enriched fractions, water, and sodium carbonate fractions. The factor score plots are shown in the left and the variable plots in the right. The color scale in the variable plots represents the average contribution of the variable to the variation explained by the two principal components. Fr: fruit; Cel: callus culture; G: green stage; W: white stage; R: red stage; Wa: water fraction; SC: sodium carbonate fraction. 


\section{KOH fraction}
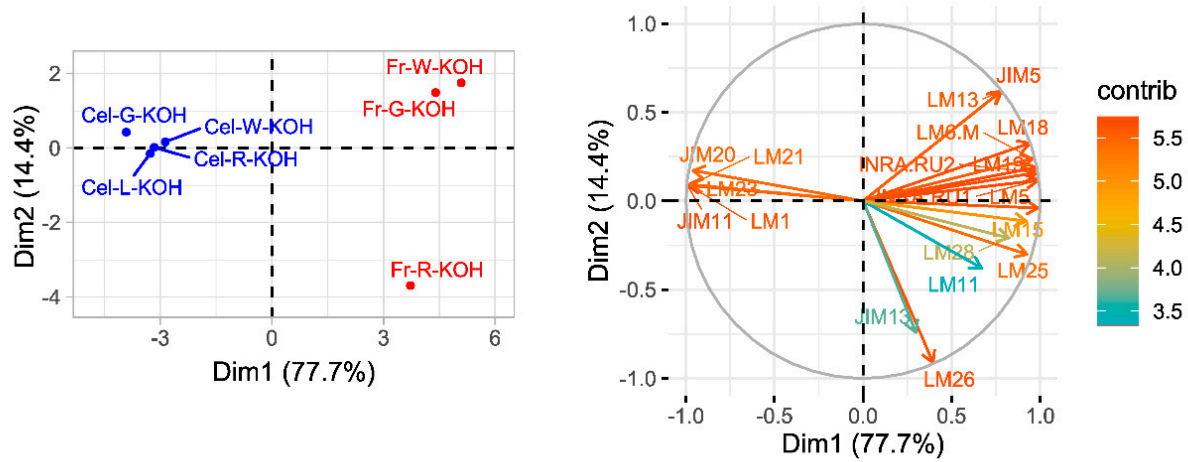

Cadoxen fraction

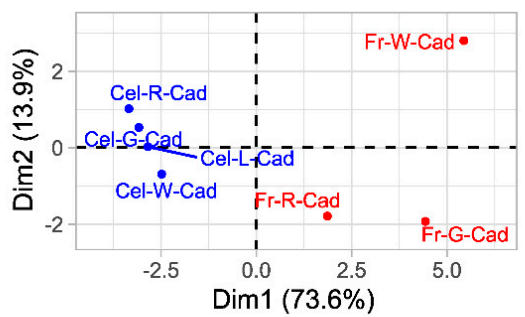

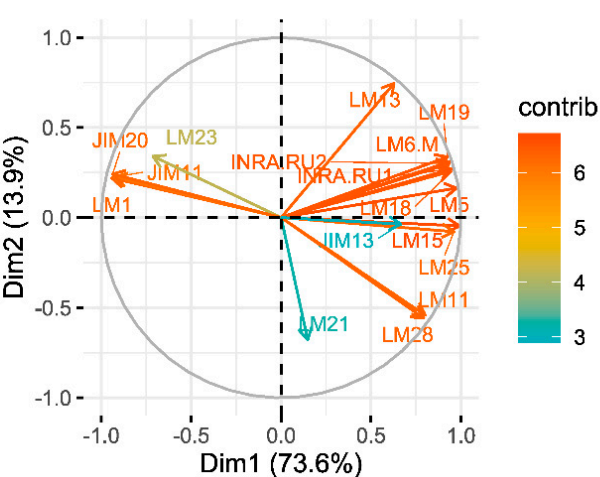

Figure 8. PCA analysis of carbohydrate microarray data from matrix glycan fractions, xyloglucans $(\mathrm{KOH})$, and cadoxen fractions. The factor score plots are shown in the left and the variable plots in the right. The color scale in the variable plots represents the average contribution of the variable to the variation explained by the two principal components. Fr: fruit; Cel: callus culture; G: green stage; $\mathrm{W}$ : white stage; R: red stage; $\mathrm{KOH}$ : $4 \mathrm{M} \mathrm{KOH}$ fraction; Cad: cadoxen fraction.

The whole set of microarray data was subjected to hierarchical clustering (Figure 9; Supplementary Figure S1). Samples were grouped in three main clusters (Figure 9). The cluster 1 comprised sodium carbonate, $\mathrm{KOH}$, and cadoxen fractions from fruit cell cultures. This group was characterized for strong signals of extensin (JIM20, JIM11, LM1), xylogalacturonan (LM23) and mannans (LM21) mAbs, and low values of RGI (INRA-RU1, LM5, LM6-M, INRA-RU2) and HG (LM18, LM19). The cluster 2 included water fractions from both cell cultures and fruits and sodium carbonate fractions from fruits. This group was defined by the high signal of HG epitopes (JIM5 and JIM7) and the low values for XG (LM15 and LM25) and extensin mAbs. Finally, the third cluster comprised $\mathrm{KOH}$ and cadoxen fractions from fruits. This clade was characterized by the large abundance of XG, RGI, and HG epitopes and the low amount of extensin. 

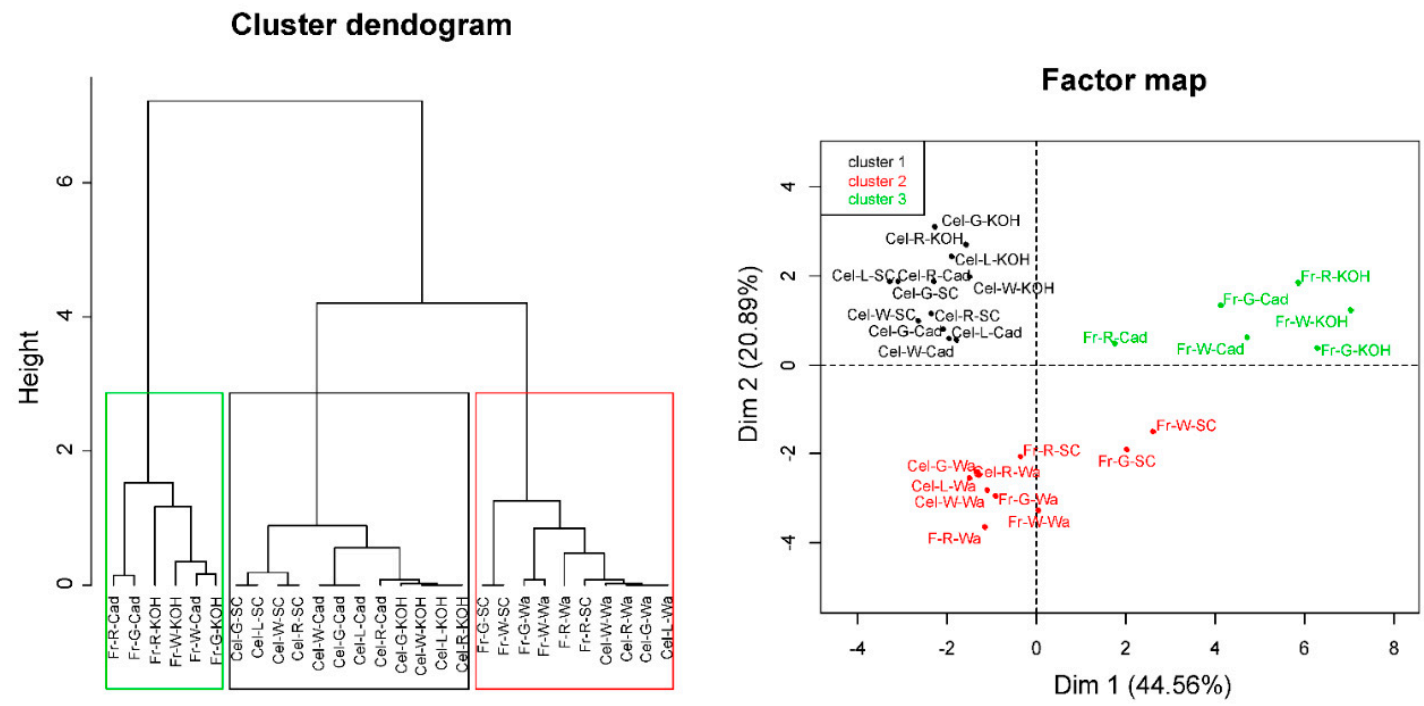

Figure 9. Hierarchical clustering of carbohydrate microarray data. Cluster dendogram based on Euclidean distances (left) and the corresponding individual factor map (right) of the different cell wall samples. Fr: fruit; Cel: callus culture; G: green stage; W: white stage; R: red stage; Wa: water fraction; SC: sodium carbonate fraction; $\mathrm{KOH}: 4 \mathrm{M} \mathrm{KOH}$ fraction, Cad: cadoxen fraction.

\section{Discussion}

\subsection{Development of Callus Cultures from Fruit Receptacle}

Callus cultures have been induced in strawberry from leaf [26], petioles [29], apical meristems [30], and immature fruit [25,31] using Murashige and Skoog (MS) [32] or Linsmaier and Skoog (LS) [33] medium supplemented with 2,4-D. Previous studies demonstrated that $\mathrm{N}_{30} \mathrm{~K}$, a mineral formulation with lower ionic strength than MS, was more suitable for micropropagation and regeneration of strawberry cv. 'Chandler' [34,35]. In this research, this medium was used successfully to obtain callus cultures in leaf explants from this genotype. The presence of 2,4-D was needed to induce callus formation, as previously observed in some strawberry genotypes [31]. The addition of BA to the induction medium diminished the amount of callus formed. Asahira and Kano [36] also found that callus was only established on a medium containing 2,4-D but lacking BA. $\mathrm{N}_{30} \mathrm{~K}$ medium supplemented with a low 2,4-D concentration was also suitable for isolation and proliferation of cell cultures from fruit receptacle at different developmental stages. Explants from red fruit showed the lowest capacity to develop callus in this medium. Similarly, the proliferation rate of the cell lines obtained diminished accordingly to the developmental age of the initial explant, being higher in green immature fruits and lower in ripe fruits. As observed in this research, Hong et al. [31] reported that the rate of callus formation from strawberry fruit decreased with the age of the explant, but they were unable to obtain callus from nearly mature fruits collected four weeks after flowering. In other species, immature fruits have also been chosen as the preferred explant to initiate cell lines [37]; to the best of our knowledge, this is the first time that callus cultures have been obtained from highly differentiated mature fruit.

\subsection{Anthocyanin Production in Strawberry Fruit Cultures}

Light slightly increased the proliferation rate of green and white callus cultures, and it induced the accumulation of red pigmentation, especially in leaf and ripe-fruit lines. A similar observation was made in cv. 'Brighton' [31]. In strawberry fruit, anthocyanin biosynthesis is regulated by the transcription factor FaMYB10. This gene is mainly expressed in ripe receptacle and directly controls the expression of early and late-regulated biosynthesis genes involved in the flavonoid/phenylpropanid pathway, including anthocyanin production genes [38]. Kadomura-Ishikawa et al. [39] found that light and ABA independently regulate FaMYB10 expression and therefore anthocyanin production in 
strawberry fruit, their effect being additive. The replacement of 2,4-D by ABA at low concentrations notably increased anthocyanin production in callus from immature green fruit but did not significantly affect that of the other lines. ABA and auxins play antagonistic effects on strawberry fruit ripening. Decreasing ABA biosynthesis in green fruit by virus induced gene silencing of FaNCDE1, a key gene in $\mathrm{ABA}$ biosynthesis, or injection of the ABA inhibitor fluridone impaired fruit development, obtaining a colorless fruit phenotype [40]. A similar phenotype was obtained when down-regulating $\mathrm{ABA}$ receptors [41]. Contrary to $\mathrm{ABA}$, auxins produced by achenes reach a maximum level in green receptacle [42], and the removal of the achenes induced the accumulation of anthocyanin [43]. The results obtained in this research suggest large differences in the regulation of the flavonoid pathway among the different fruit cell lines. Auxin/ABA hormonal balance seems to be the main regulator of anthocyanin production in the cell line from green fruits; however, cultures from ripe fruits mainly respond to light, while those from white fruits showed a low capacity for anthocyanin production. The differential behavior of the fruit cell lines could be exploited to decipher the genetic regulation of pigment accumulation in strawberry fruit.

\subsection{Characterization of Cell Walls from Cell Cultures}

The pectin profile in cell wall fractions isolated from fruits showed that the amounts of HG and RGI epitopes increased from green to white fruit and then declined in red ripe fruit to very low levels. This pattern was observed in all fractions analyzed except in the water fraction from ripe fruit that contained significant amounts of low methyl ester HG recognized by JIM5. These findings support previous observations of pectin solubilization, i.e., a reduction in the amount of pectins tightly bound to the cell wall concomitant to an increase in water-soluble pectins as a typical feature of strawberry remodeling during fruit ripening [4,44-46]. It is noteworthy that a large fraction of pectins, especially RGI, was extracted with $\mathrm{KOH}$ and cadoxen. Pectin and xyloglucan can be covalently linked [47,48] and recently, Cornuault et al. [49] found that a sub-population of pectin was attached to XG in $\mathrm{KOH}$ fractions from different fruits, including strawberry. As regards hemicellulose, it has been reported that its content diminished during strawberry ripening in cultivars with contrasting fruit firmness $[50,51]$. Contrary to those results, the carbohydrate microarray showed that the signal intensity of extractable XG epitopes changed little during ripening of 'Chandler' fruit; however, the results obtained suggest a change in the chemical structure of XG in ripe fruit, increasing the amount of galactosylated XG recognized by LM25. Significant amounts of glucuronoxylans were also detected in $\mathrm{KOH}$ and cadoxen extracts and with an intriguing pattern of relatively lower abundance in white fruit. Heteroxylans are not abundant in primary cell walls of dicotyledonous plants, and the role of glucuronoxylan is unknown. Cornuault et al. [52] found glucuronoxylan associated with RGI-enriched fraction from potato tubers. However, our results indicate a negative correlation between the glucuronoxylan signal and RGI abundance in matrix glycan fractions.

Carbohydrate profiles from cell cultures were quite different from fruit. In callus cell walls, pectin antibodies showed a very weak signal. By contrast, callus cell wall extracts were enriched in extensin epitopes associated with tightly bound pectins (sodium carbonate fraction) and matrix glycans. Extensins are one of the main classes of hydroxyproline-rich glycoproteins (HRGPs) that contain multiple Ser-(Pro)3-5 repeats and Tyr motifs acting as cross-link sites $[53,54]$. These proteins are involved in the building and the maintenance of primary cell wall. During the cell plate formation, the self-assembling ability of extensins generates scaffolding networks that may serve as a template for pectin matrix assembly due to the acid-base interactions between extensin and pectin [53]. On the other hand, extensin cross-linking strengthens cell walls and many biotic and abiotic stresses induce extensin biosynthesis, e.g., pathogen attack or wounding [55-57]. In grape berries, extensin epitopes detected with LM1 and JIM20 increased at véraison when ripening started; however, its physiological function was unclear [58]. Contrary to grape, the CoMPP analysis showed that extensin was a minor component in the strawberry cell wall during fruit development. The high extensin content in the strawberry cell cultures may reflect a tightly cross-linked cell wall and could be related to the stressful conditions of 
in vitro tissue culture; in fact, high amounts of extensin have also been found in suspension cells from other species $[59,60]$. The stronger extensin epitope signals were detected in sodium carbonate fraction, especially in leaf and green fruit lines, suggesting that these proteins might be linked to pectins, as reported by [61]. This interaction could also explain the low label of $\mathrm{mAb}$ against pectins, i.e., pectin epitopes might be masked in pectin-extensin complexes, resulting in a low binding efficiency of HG and RGI antibodies. Indeed, pectin and other cell wall polysaccharides may be more tightly linked into the cell wall structures of callus cells and therefore less extractable to appear in the solubilized fractions. On the other hand, LM23 binding was detected in all cell wall fractions from callus samples except water, indicating the presence of xylogalacturonan (XGA) epitopes. This pectin has not previously been described in strawberry fruit, but it has been found in hairy regions of apple pectin, another member of Rosaceae family [62]. XGA has been related to cell adhesion in carrot-cultured cells [63].

Carbohydrate microarrays provide information about the relative levels of glycan epitopes but do not allow quantifying absolute levels of cell wall components [64]. In callus cultures, the large amounts of extensin and the apparent lower presence of pectin epitopes make it difficult to compare these cell walls with their corresponding samples from fruits using this approach. However, the hierarchical clustering of microarray data included in the same group the water fractions from both kinds of samples jointly with sodium carbonate fractions from fruits. It is therefore likely that pectin composition in these fractions were comparable. As previously indicated, polyuronides are extensively modified during strawberry ripening $[4,44]$. Other techniques such as carbohydrate structural analyses would be needed to precisely determine whether cell walls at different fruit developmental stages and their corresponding cell lines are equivalent. Preliminary ELISA experiments showed that the quantification of unesterified HG detected by LM19 in the sodium carbonate fraction followed the same trend in cell cultures as the one observed in the microarray for fruit stages (result not shown). Experiments are in progress to determine if the same occurs with other pectin epitopes.

\section{Materials and Methods}

\subsection{Plant Material and Callus Development}

Strawberry (Fragaria $\times$ ananassa Duch.) plants, cv. 'Chandler', micropropagated in $\mathrm{N}_{30} \mathrm{~K}$ mineral formulation [65] with MS [32] microelements and vitamins, as described by [34], were used as a source of leaf explants. Fruits at different developmental stages, unripe-green, white, and fully ripe-red, were harvested from 'Chandler' plants growing in a greenhouse.

For callus induction, twenty leaf disks from in vitro plants were cultured in Petri dishes containing $\mathrm{N}_{30} \mathrm{~K}$ medium supplemented with BA $(0,2.2$ and $4.4 \mu \mathrm{M})$ and 2,4-D $(0,11.3,22.6$, and $45.2 \mu \mathrm{M})$. Fruits, 10-20 fruits per developmental stage, were washed with water and sterilized in a 10\% commercial bleach solution with $100 \mu \mathrm{L}$ of Tween-20 for $15 \mathrm{~min}$. Then, fruits were peeled to remove achenes, sterilized again as previously described, and washed three times with sterile water. Sections of cortical tissue, $0.5 \times 0.5 \mathrm{~cm}$, were dissected and cultured in $25 \times 150 \mathrm{~mm}$ test tubes containing $\mathrm{N}_{30} \mathrm{~K}$ medium supplemented with $11.3 \mu \mathrm{M}$ 2,4-D. In all cases, culture media were solidified with $8 \mathrm{~g} / \mathrm{L}$ agar and autoclaved for $15 \mathrm{~min}$ at $121{ }^{\circ} \mathrm{C}$ and $1.05 \mathrm{~kg} / \mathrm{cm}^{2}$. Explants were cultured in the dark at $25 \pm 2{ }^{\circ} \mathrm{C}$ and subcultured to fresh medium every two weeks. Once induced, leaf and fruit calli were isolated from the explant and cultured in $\mathrm{N}_{30} \mathrm{~K}$ medium supplemented with $11.3 \mu \mathrm{M} 2,4-\mathrm{D}$, with subculturing at 4 week intervals. Afterwards, a single cell line from each explant type was selected and multiplied for further studies.

The effect of darkness vs. light incubation on the growth of the different cell lines was analyzed. Callus tissues, $0.3 \mathrm{~g}$, were inoculated in test tubes containing $20 \mathrm{~mL}$ of $\mathrm{N}_{30} \mathrm{~K}$ medium supplemented with $11.3 \mu \mathrm{M}$ 2,4-D. Cultures were incubated either in darkness or under a $16 \mathrm{~h}$ photoperiod at $40 \mu \mathrm{mol} \cdot \mathrm{m}^{-2} \cdot \mathrm{s}^{-1}$ provided by Sylvania Gro-lux lamps, and the fresh weight was recorded after 4 weeks of culture. Five tubes per treatment and cell line were employed, and the experiment was repeated twice. 


\subsection{Effect of ABA on Anthocyanin Production}

Three hundred mg aliquots of each cell line were transferred to test tubes containing $\mathrm{N}_{30} \mathrm{~K}$ medium supplemented with ABA at different concentrations $(0,1,10$, and $100 \mu \mathrm{M})$ and incubated in light ( $16 \mathrm{~h}$ photoperiod of $40 \mu \mathrm{mol} \cdot \mathrm{m}^{-2} \cdot \mathrm{s}^{-1}$ ) for 14 days. Two control treatments consisting of calli cultured in $\mathrm{N}_{30} \mathrm{~K}$ medium either supplemented with $11.3 \mu \mathrm{M}$ 2.4-D or without growth regulators were also employed. After 14 days, the calli were visually inspected for the presence of red coloration, frozen in liquid nitrogen, and stored at $-80^{\circ} \mathrm{C}$ until used. Five tubes per treatment were employed, and the experiment was repeated twice.

For anthocyanin extraction, frozen callus was pulverized with a mortar and pestle in liquid nitrogen. Then, $0.3 \mathrm{~g}$ were incubated in $3 \mathrm{~mL} \mathrm{MeOH}-\mathrm{HCl}(99: 1, v / v)$ for $4 \mathrm{~h}$ at $4{ }^{\circ} \mathrm{C}$ in darkness. The homogenate was centrifuged at $10,000 \times g$ for $15 \mathrm{~min}$, and the absorbance at $515 \mathrm{~nm}$ of the supernatant was measured. As pelargonidin 3-glucoside is the main anthocyanin compound in strawberry fruit, anthocyanin concentration was expressed as $\mathrm{mg} / 100 \mathrm{~g}$ of callus of pelargonidin 3-glucoside using an extinction coefficient of $17,333 \mathrm{~L} \cdot \mathrm{mol}^{-1} \cdot \mathrm{cm}^{-1}$ [66]. Three independent extractions per treatment and cell line were performed.

\subsection{Cell Wall Extraction}

Fruit receptacle and callus from cell cultures grown in $\mathrm{N}_{30} \mathrm{~K}$ medium supplemented with $11.3 \mu \mathrm{M}$ 2,4-D for four weeks were frozen, finely milled to powder under liquid nitrogen, and extracted with PAW (phenol: acetic acid: water, 2:1:1, w: $v: v$ ) as reported by [67]. Briefly, $10 \mathrm{~g}$ of sample powder were extracted with $20 \mathrm{~mL}$ of PAW, centrifuged at $4000 \times g$, and the pellets were de-starched by aqueous DMSO 90\% treatment. The final residue, cell wall extract, was lyophilized prior to fractionation. Three independent extractions per fruit stage and cell line were performed.

\subsection{Comprehensive Microarray Polymer Profiling (CoMPP)}

Cell wall carbohydrate microarrays were performed as previously described [68]. Cell walls were sequentially extracted with sterile water, $0.1 \mathrm{M} \mathrm{Na}_{2} \mathrm{CO}_{3}, 4 \mathrm{M} \mathrm{KOH}$, and cadoxen (31\% 1,2-diaminoethane with $0.78 \mathrm{M}$ cadmium oxide, (v:v)) using a tissue lyser (Retsch MM400 mixer mill Retsch GmbH, Haan, Germany). Both alkaline fractions included $0.1 \% \mathrm{NaBH}_{4}$ freshly added just before use. For the first water-soluble fraction, $10 \mathrm{mg}$ of cell wall extract were homogenized in tissue lyser with $500 \mu \mathrm{L}$ of water at $30 \mathrm{~Hz}$ shaking for $20 \mathrm{~min}$, followed by gentle rocking $1 \mathrm{~h}$ at RT. After centrifugation at $2700 \times g$ for $15 \mathrm{~min}$, supernatants were saved in a fresh tube and stored as water-fraction, while pellets were further extracted with the next solvent following the same extraction steps. Supernatants of each fraction were diluted four times (first dilution 1:1 and five-fold for the following dilutions) and printed as four technical replicates, giving a 16-spots sub-array per sample. All samples were printed simultaneously on the same sheet of nitrocellulose as adjacent arrays. Printing onto nitrocellulose was performed by an ArrayJet Sprint (ArrayJet, Roslin, UK) and quantified as previously described [68]. In brief, the printed nitrocellulose sheets were probed with the primary mAbs diluted (1/10) in phosphate-buffered saline (PBS) containing $5 \%$ w/v milk powder (MPBS). Secondary anti-rat or anti-mouse antibodies conjugated to alkaline phosphatase (Sigma-Aldrich, St. Louis, Missouri, US) were diluted (1/5000) in MPBS. Primary mAbs used in this study (Table 1 and Supplementary Table S1) were from PlantProbes (Leeds, UK) except INRA-RU1 and INRA-RU2, which were kindly provided by M.C. Ralet (Biopolymères Interactions Assemblages, Nantes, France). Developed microarrays were scanned (CanoScan 8800F), converted to TIFFs, and signals were processed by ImaGene 6.0 microarray analysis software (BioDiscovery), as described before [62]. The mean spot signals obtained from four experiments are presented in heat maps in which color intensity was correlated to signal. The highest signal in each dataset was set to 100, and all other values were normalized accordingly. 


\subsection{Statistical Analysis}

Data were subjected to analysis of variance (ANOVA) using IBM SPSS Statistics software, version 25. Levene test for homogeneity of variance was performed prior to ANOVA. Tukey and Kruskal-Wallis tests were used for mean separation in the case of homogeneous and non-homogeneous variances, respectively. Normalized values obtained in the carbohydrate microarray experiment were subjected to principal component analysis using the R package FactoMineR. All tests were performed at $p=0.05$.

\section{Conclusions}

The results obtained in this research suggest that cell cultures obtained from strawberry receptacle at different developmental stages could be a useful model system to achieve a better understanding of the ripening process in strawberry. Metabolic pathways involved in anthocyanin production or hormonal regulation of ripening could be investigated using this system. Despite the differences observed in cell wall composition in fruits and callus cultures, some aspects of cell wall disassembly during fruit development, e.g., pectin remodeling, could also be addressed using this system.

Supplementary Materials: The following are available online at http://www.mdpi.com/2223-7747/9/7/805/s1, Figure S1: Variables factor map obtained in the PCA analysis of the whole set of carbohydrate microarray data. Table S1: List of monoclonal antibodies used in the carbohydrate microarray and the epitopes recognized by each $\mathrm{mAb}$.

Author Contributions: Conceptualization, S.P., F.P.-A., and J.A.M.; Formal analysis, J.P.K., S.P., and J.A.M.; Funding acquisition, A.J.M. and J.A.M.; Investigation, P.R.-V., M.B., J.A.R., S.C., and J.S.; Supervision, S.C. and A.J.M.; Writing-original draft, J.A.M.; Writing—review \& editing, J.P.K., S.P., F.P-A., and J.A.M. All authors have read and agreed to the published version of the manuscript.

Funding: This research was funded by MINISTERIO DE CIENCIA, INNOVACIÓN Y UNIVERSIDADES and FEDER EU, grant numbers AGL2014-55784-C2-1-R and AGL2017-86531-C2-1-R.

Acknowledgments: We thanks M. C. Ralet (Biopolymères Interactions Assemblages, Nantes, France) for kindly provide INRA-RU antibodies. P.R.-V. was awarded a Ph.D. Fellowship from Ministerio de Ciencia, Innovación y Universidades (BES-2015-073616). Ph.D. Program Advanced Biotechnology, University of Málaga.

Conflicts of Interest: The authors declare no conflict of interest.

\section{References}

1. Giovannoni, J.J. Genetic regulation of fruit development and ripening. Plant Cell 2004, 16, 170-180. [CrossRef] [PubMed]

2. Contador, L.; Shinya, P.; Infante, R. Texture phenotyping in fresh fleshy fruit. Sci. Hortic. 2015, 193, 40-46. [CrossRef]

3. Goulao, L.; Oliveira, C. Cell wall modifications during fruit ripening: When a fruit is not the fruit. Trends Food Sci. Technol. 2008, 19, 4-25. [CrossRef]

4. Moya-León, M.A.; Mattus-Araya, E.; Herrera, R. Molecular events occurring during softening of strawberry fruit. Front. Plant Sci. 2019, 10, 615. [CrossRef] [PubMed]

5. Perkins-Veazie, P. Growth and ripening of strawberry fruit. Hortic. Rev. 1995, 17, 267-297.

6. Brummell, D.A. Cell wall disassembly in ripening fruit. Funct. Plant Biol. 2006, 33, 103-119. [CrossRef]

7. Brummell, D.A.; Harpster, M.H. Cell wall metabolism in fruit softening and quality and its manipulation in transgenic plants. Plant Mol. Biol. 2001, 47, 311-340. [CrossRef]

8. Posé, S.; Paniagua, C.; Matas, A.J.; Gunning, A.P.; Morris, V.J.; Quesada, M.A.; Mercado, J.A. A nanostructural view of the cell wall disassembly process during fruit ripening and postharvest storage by atomic force microscopy. Trends Food Sci. Technol. 2018, 87, 47-58. [CrossRef]

9. Wang, D.; Yeats, T.H.; Uluisik, S.; Rose, J.K.C.; Seymour, G.B. Fruit softening: Revisiting the role of pectin. Trends Plant Sci. 2018, 23, 302-310. [CrossRef]

10. Jiménez-Bermúdez, S.; Redondo-Nevado, J.; Muñoz-Blanco, J.; Caballero, J.L.; López-Aranda, J.M.; Valpuesta, V.; Pliego-Alfaro, F.; Quesada, M.A.; Mercado, J.A. Manipulation of strawberry fruit softening by antisense expression of a pectate lyase gene. Plant Physiol. 2002, 128, 751-759. [CrossRef] 
11. Posé, S.; Paniagua, C.; Cifuentes, M.; Blanco-Portales, R.; Quesada, M.A.; Mercado, J.A. Insights into the effects of polygalacturonase FaPG1 gene silencing on pectin matrix disassembly, enhanced tissue integrity, and firmness in ripe strawberry fruits. J. Exp. Bot. 2013, 64, 3803-3815. [CrossRef] [PubMed]

12. Schaart, J.G.; Dubos, C.; Romero De La Fuente, I.; van Houwelingen, A.M.M.L.; de Vos, R.C.H.; Jonker, H.H.; Xu, W.; Routaboul, J.-M.; Lepiniec, L.; Bovy, A.G. Identification and characterization of MYB-bHLH-WD40 regulatory complexes controlling proanthocyanidin biosynthesis in strawberry (Fragaria $\times$ ananassa) fruits. New Phytol. 2013, 197, 454-467. [CrossRef] [PubMed]

13. Silva, F.L.D.; Escribano-Bailón, M.T.; Alonso, J.J.P.; Rivas-Gonzalo, J.C.; Santos-Buelga, C. Anthocyanin pigments in strawberry. LWT Food Sci. Technol. 2007, 40, 374-382. [CrossRef]

14. Gao, Q.; Luo, H.; Li, Y.; Liu, Z.; Kang, C. Genetic modulation of RAP alters fruit coloration in both wild and cultivated strawberry. Plant Biotechnol. J. 2020, 18, 1550-1561. [CrossRef]

15. Palomo-Ríos, E.; Quesada, M.A.; Matas, A.J.; Pliego-Alfaro, F.; Mercado, J.A. The history and current status of genetic transformation in berry crops. In The Genomes of Rosaceous Berries and Their Wild Relatives; Hytönen, T., Graham, J., Harrison, R., Eds.; Springer International Publishing: Cham, Switzerland, 2018; pp. 139-160. [CrossRef]

16. Wang, H.; Zhang, H.; Yang, Y.; Li, M.; Zhang, Y.; Liu, J.; Dong, J.; Li, J.; Butelli, E.; Xue, Z.; et al. The control of red colour by a family of MYB transcription factors in octoploid strawberry (Fragaria $\times$ ananassa) fruits. Plant Biotechnol. J. 2019, 18, 1169-1184. [CrossRef]

17. Fenning, T.M. The use of tissue culture and in-vitro approaches for the study of tree diseases. Plant Cell Tissue Organ Cult. 2019, 136, 415-430. [CrossRef]

18. Fernandes, J.C.; García-Angulo, P.; Goulao, L.F.; Acebes, J.L.; Amâncio, S. Mineral stress affects the cell wall composition of grapevine (Vitis vinifera L.) callus. Plant Sci. 2013, 205-206, 111-120. [CrossRef]

19. Liu, J.H.; Nada, K.; Honda, C.; Kitashiba, H.; Wen, X.P.; Pang, X.M.; Moriguchi, T. Polyamine biosynthesis of apple callus under salt stress: Importance of the arginine decarboxylase pathway in stress response. J. Exp. Bot. 2006, 57, 2589-2599. [CrossRef]

20. Perez-Garcia, P.; Moreno-Risueno, M.A. Stem cells and plant regeneration. Dev. Biol. 2018, 442, 3-12. [CrossRef]

21. Cohen, J.D. In vitro tomato fruit cultures demonstrate a role for indole-3-acetic acid in regulating fruit ripening. J. Am. Soc. Hortic. Sci. 1996, 121, 520-524. [CrossRef]

22. Ishida, B.K.; Baldwin, E.A.; Buttery, R.G.; Chui, S.H.; Ling, L.C. Flavor volatiles, sugars and color development in ripening in vitro-cultured tomato fruit and calyx. Physiol. Plant. 1993, 89, 861-867. [CrossRef]

23. Belhadj, A.; Telef, N.; Saigne, C.; Cluzet, S.; Barrieu, F.; Hamdi, S.; Mérillon, J.-M. Effect of methyl jasmonate in combination with carbohydrates on gene expression of PR proteins, stilbene and anthocyanin accumulation in grapevine cell cultures. Plant Physiol. Biochem. 2008, 46, 493-499. [CrossRef] [PubMed]

24. Arnaldos, T.L.; Ferrer, M.A.; García, A.A.C.; Muñoz, R. Changes in peroxidase activity and isoperoxidase pattern during strawberry (Fragaria $\times$ ananassa) callus development. J. Plant Physiol. 2002, 159, 429-435. [CrossRef]

25. López Arnaldos, T.; Muñoz, R.; Ferrer, M.A.; Calderón, A.A. Changes in phenol content during strawberry (Fragaria $\mathrm{x}$ ananassa, cv. Chandler) callus culture. Physiol. Plant. 2001, 113, 315-322. [CrossRef]

26. Mori, T.; Sakurai, M.; Seki, M.; Furusaki, S. Use of auxin and cytokinin to regulate anthocyanin production and composition in suspension cultures of strawberry cell. J. Sci. Food Agric. 1994, 65, 271-276. [CrossRef]

27. Zhang, W.; Furusaki, S. Regulation of anthocyanin synthesis in suspension cultures of strawberry cell by $\mathrm{pH}$. Biotechnol. Lett. 1997, 19, 1057-1061. [CrossRef]

28. Alayón-Luaces, P.; Ponce, N.M.A.; Mroginski, L.A.; Stortz, C.A.; Sozzi, G.O. Compositional changes in cell wall polysaccharides from apple fruit callus cultures modulated by different plant growth regulators. Plant Sci. 2012, 185-186, 169-175. [CrossRef]

29. Edahiro, J.; Seki, M. Phenylpropanoid metabolite supports cell aggregate formation in strawberry cell suspension culture. J. Biosci. Bioeng. 2006, 102, 8-13. [CrossRef]

30. Sato, K.; Nakayama, M.; Shigeta, J. Culturing conditions affecting the production of anthocyanin in suspended cell cultures of strawberry. Plant Sci. 1996, 113, 91-98. [CrossRef]

31. Hong, Y.C.; Read, P.E.; Harlander, S.K.; Labuza, T.P. Development of a tissue culture system from immature strawberry fruits. J. Food Sci. 1989, 54, 388-392. [CrossRef] 
32. Murashige, T.; Skoog, F. A revised medium for rapid growth and bio assays with tobacco tissue cultures. Physiol. Plant. 1962, 15, 473-497. [CrossRef]

33. Linsmaier, E.M.; Skoog, F. Organic growth factor requirements of tobacco tissue cultures. Physiol. Plant. 1965, 18, 100-127. [CrossRef]

34. Barceló, M.; El-Mansouri, I.; Mercado, J.A.; Quesada, M.A.; Pliego-Alfaro, F. Regeneration and transformation via Agrobacterium tumefaciens of the strawberry cultivar Chandler. Plant Cell Tissue Organ Cult. 1998, 54, 29-36. [CrossRef]

35. López-Aranda, J.M.; Pliego-Alfaro, F.; López-Navidad, I.; Barceló-Muñoz, M. Micropropagation of strawberry (Fragaria $\mathrm{x}$ ananassa Duch.). Effect of mineral salts, benzyladenine levels and number of subcultures on the in vitro and field behaviour of the obtained microplants and the fruiting capacity of their progeny. J. Hortic. Sci. 1994, 69, 625-637. [CrossRef]

36. Asahira, T.; Kano, Y. Shoot formation from cultured tissue of strawberry fruits. J. Jpn. Soc. Hortic. Sci. 1977, 46, 317-324. [CrossRef]

37. Alayón-Luaces, P.; Pagano, E.A.; Mroginski, L.A.; Sozzi, G.O. Four glycoside hydrolases are differentially modulated by auxins, cytokinins, abscisic acid and gibberellic acid in apple fruit callus cultures. Plant Cell Tissue Organ Cult. 2008, 95, 257-263. [CrossRef]

38. Medina-Puche, L.; Cumplido-Laso, G.; Amil-Ruiz, F.; Hoffmann, T.; Ring, L.; Rodríguez-Franco, A.; Caballero, J.L.; Schwab, W.; Muñoz-Blanco, J.; Blanco-Portales, R. MYB10 plays a major role in the regulation of flavonoid/phenylpropanoid metabolism during ripening of Fragaria $\times$ ananassa fruits. J. Exp. Bot. 2014, 65, 401-417. [CrossRef]

39. Kadomura-Ishikawa, Y.; Miyawaki, K.; Takahashi, A.; Masuda, T.; Noji, S. Light and abscisic acid independently regulated FaMYB10 in Fragaria $\times$ ananassa fruit. Planta 2015, 241, 953-965. [CrossRef]

40. Jia, H.-F.; Chai, Y.-M.; Li, C.-L.; Lu, D.; Luo, J.-J.; Qin, L.; Shen, Y.-Y. Abscisic acid plays an important role in the regulation of strawberry fruit ripening. Plant Physiol. 2011, 157, 188-199. [CrossRef]

41. Chai, Y.-M.; Jia, H.-F.; Li, C.-L.; Dong, Q.-H.; Shen, Y.-Y. FaPYR1 is involved in strawberry fruit ripening. J. Exp. Bot. 2011, 62, 5079-5089. [CrossRef]

42. Estrada-Johnson, E.; Csukasi, F.; Pizarro, C.M.; Vallarino, J.G.; Kiryakova, Y.; Vioque, A.; Brumos, J.; Medina-Escobar, N.; Botella, M.A.; Alonso, J.M.; et al. Transcriptomic analysis in strawberry fruits reveals active auxin biosynthesis and signaling in the ripe receptacle. Front. Plant Sci. 2017, 8, 889. [CrossRef] [PubMed]

43. Given, N.K.; Venis, M.A.; Grierson, D. Hormonal regulation of ripening in the strawberry, a non-climacteric fruit. Planta 1988, 174, 402-406. [CrossRef] [PubMed]

44. Paniagua, C.; Santiago-Doménech, N.; Kirby, A.R.; Gunning, A.P.; Morris, V.J.; Quesada, M.A.; Matas, A.J.; Mercado, J.A. Structural changes in cell wall pectins during strawberry fruit development. Plant Physiol. Biochem. 2017, 118, 55-63. [CrossRef] [PubMed]

45. Quesada, M.A.; Blanco-Portales, R.; Pose, S.; Garcia-Gago, J.A.; Jiménez-Bermúdez, S.; Muñoz-Serrano, A.; Caballero, J.L.; Pliego-Alfaro, F.; Mercado, J.A.; Muñoz-Blanco, J. Antisense down-regulation of the FaPG1 gene reveals an unexpected central role for polygalacturonase in strawberry fruit softening. Plant Physiol. 2009, 150, 1022-1032. [CrossRef] [PubMed]

46. Redgwell, R.J.; Macrae, E.; Hallett, I.; Fischer, M.; Perry, J.; Harker, R. In vivo and in vitro swelling of cell walls during fruit ripening. Planta 1997, 64, 162-173. [CrossRef]

47. Popper, Z.A.; Fry, S.C. Widespread occurrence of a covalent linkage between xyloglucan and acidic polysaccharides in suspension-cultured angiosperm cells. Ann. Bot. 2005, 96, 91-99. [CrossRef]

48. Thompson, J.E.; Fry, S.C. Evidence for covalent linkage between xyloglucan and acidic pectins in suspension-cultured rose cells. Planta 2000, 211, 275-286. [CrossRef]

49. Cornuault, V.; Posé, S.; Knox, J.P. Disentangling pectic homogalacturonan and rhamnogalacturonan-I polysaccharides: Evidence for sub-populations in fruit parenchyma systems. Food Chem. 2018, 246, 275-285. [CrossRef]

50. Heng Koh, T.; Melton, L.D. Ripening-related changes in cell wall polysaccharides of strawberry cortical and pith tissues. Postharvest Biol. Technol. 2002, 26, 23-33. [CrossRef]

51. Rosli, H.G.; Civello, P.M.; Martínez, G.A. Changes in cell wall composition of three Fragaria $\mathrm{x}$ ananassa cultivars with different softening rate during ripening. Plant Physiol. Biochem. 2004, 42, 823-831. [CrossRef] 
52. Cornuault, V.; Buffetto, F.; Rydahl, M.G.; Marcus, S.E.; Torode, T.A.; Xue, J.; Crépeau, M.-J.; Faria-Blanc, N.; Willats, W.G.T.; Dupree, P.; et al. Monoclonal antibodies indicate low-abundance links between heteroxylan and other glycans of plant cell walls. Planta 2015, 242, 1321-1334. [CrossRef] [PubMed]

53. Lamport, D.T.A.; Kieliszewski, M.J.; Chen, Y.; Cannon, M.C. Role of the extensin superfamily in primary cell wall architecture. Plant Physiol. 2011, 156, 11-19. [CrossRef] [PubMed]

54. Marzol, E.; Borassi, C.; Bringas, M.; Sede, A.; Rodríguez Garcia, D.R.; Capece, L.; Estevez, J.M. Filling the gaps to solve the extensin puzzle. Mol. Plant 2018, 11, 645-658. [CrossRef] [PubMed]

55. Liu, X.; Wolfe, R.; Welch, L.R.; Domozych, D.S.; Popper, Z.A.; Showalter, A.M. Bioinformatic identification and analysis of extensins in the plant kingdom. PLOS ONE 2016, 11, e0150177. [CrossRef] [PubMed]

56. Merkouropoulos, G.; Shirsat, A.H. The unusual Arabidopsis extensin gene atExt1 is expressed throughout plant development and is induced by a variety of biotic and abiotic stresses. Planta 2003, 217, 356-366. [CrossRef]

57. Portieles, R.; Canales, E.; Hernández, I.; López, Y.; Rodríguez, M.; Rodríguez, M.; Terauchi, R.; Borroto, C.; Santos, R.; Ayra-Pardo, C.; et al. NmEXT Extensin gene: A positive regulator of resistance response against the oomycete Phytophthora nicotianae. Plant Mol. Biol. Rep. 2018, 36, 484-490. [CrossRef]

58. Moore, J.P.; Fangel, J.U.; Willats, W.G.T.; Vivier, M.A. Pectic- $\beta(1,4)$-galactan, extensin and arabinogalactan-protein epitopes differentiate ripening stages in wine and table grape cell walls. Ann. Bot. 2014, 114, 1279-1294. [CrossRef]

59. Dey, P.M.; Brownleader, M.D.; Pantelides, A.T.; Trevan, M.; Smith, J.J.; Saddler, G. Extensin from suspension-cultured potato cells: A hydroxyproline-rich glycoprotein, devoid of agglutinin activity. Planta 1997, 202, 179-187. [CrossRef]

60. Jackson, P.A.P.; Galinha, C.I.R.; Pereira, C.S.; Fortunato, A.; Soares, N.C.; Amâncio, S.B.Q.; Pinto Ricardo, C.P. Rapid deposition of extensin during the elicitation of grapevine callus cultures is specifically catalyzed by a 40-kilodalton peroxidase. Plant Physiol. 2001, 127, 1065-1076. [CrossRef]

61. Nunez, A.; Fishman, M.L.; Fortis, L.L.; Cooke, P.H.; Hotchkiss, A.T. Identification of extensin protein associated with sugar beet pectin. J. Agric. Food Chem. 2009, 57, 10951-10958. [CrossRef]

62. Schols, H.A.; Bakx, E.J.; Schipper, D.; Voragen, A.G.J. A xylogalacturonan subunit present in the modified hairy regions of apple pectin. Carbohydr. Res. 1995, 279, 265-279. [CrossRef]

63. Satoh, S. Functions of the cell wall in the interactions of plant cells: Analysis using carrot cultured cells. Plant Cell Physiol. 1998, 39, 361-368. [CrossRef]

64. Moller, I.; Sørensen, I.; Bernal, A.J.; Blaukopf, C.; Lee, K.; Øbro, J.; Pettolino, F.; Roberts, A.; Mikkelsen, J.D.; Knox, J.P.; et al. High-throughput mapping of cell-wall polymers within and between plants using novel microarrays. Plant J. 2007, 50, 1118-1128. [CrossRef] [PubMed]

65. Margara, J. Bases de la Multiplication Vegetative; INRA: Versailles, Paris, France, 1984.

66. Giusti, M.M.; Rodríguez-Saona, L.E.; Wrolstad, R.E. Molar absorptivity and color characteristics of acylated and non-acylated pelargonidin-based anthocyanins. J. Agric. Food Chem. 1999, 47, 4631-4637. [CrossRef]

67. Redgwell, R.J.; Melton, L.D.; Brasch, D.J. Cell wall dissolution in ripening kiwifruit (Actinidia deliciosa): Solubilization of the pectic polymers. Plant Physiol. 1992, 98, 71-81. [CrossRef]

68. Kračun, S.K.; Fangel, J.U.; Rydahl, M.G.; Pedersen, H.L.; Vidal-Melgosa, S.; Willats, W.G.T. Carbohydrate microarray technology applied to high-throughput mapping of plant cell wall glycans using Comprehensive Microarray Polymer Profiling (CoMPP). In High-Throughput Glycomics and Glycoproteomics: Methods and Protocols. Methods in Molecular Biology; Lauc, G., Wuhrer, M., Eds.; Humana Press: New York, NY, USA, 2017; Volume 1503, pp. 147-165. [CrossRef]

(C) 2020 by the authors. Licensee MDPI, Basel, Switzerland. This article is an open access article distributed under the terms and conditions of the Creative Commons Attribution (CC BY) license (http://creativecommons.org/licenses/by/4.0/). 